\title{
ARTICLE
}

Received 30 Jan 2017 | Accepted 19 Jun 2017 | Published 25 Jul 2017

\section{Interiority in Sloterdijk and Deleuze}

\author{
Judith Wambacq ${ }^{1}$ and Sjoerd van Tuinen ${ }^{2}$
}

\begin{abstract}
This article constitutes one of the first comparisons between the philosophies of Peter Sloterdijk and the philosophical tandem Gilles Deleuze-Félix Guattari. The subject of the discussion between both philosophical positions is on communication with the exterior, and thus also how an interiority is to be conceived. Both philosophers raise these questions in reference to the work of the Estonian biologist Jacob von Uexküll. At first sight, Sloterdijk's focus on immunity mechanisms seems to suggest a preference for restricting this communication, whereas Deleuze and Guattari's interest in becomings seems to direct us in the opposite direction. However, a closer examination of both positions reveals that the difference lies in the nature of their approaches: whereas Deleuze and Guattari's interest in opening up interiorities is ontologically motivated, Sloterdijk's focus on shielding them off is existential. These findings might help us in demining the opposition between progressive socialism and conservatism.
\end{abstract}

\footnotetext{
${ }^{1}$ School of Arts, University College Ghent, Ghent, Belgium ${ }^{2}$ Erasmus University Rotterdam, Rotterdam, The Netherlands Correspondence: (e-mail: judith. wambacq@hogent.be)
} 


\section{Introduction}

ne of the philosophical authors that immediately comes to mind in the context of interiority and its link with the notion of the interior is the German philosopher Peter Sloterdijk. Between 1998 and 2004, Sloterdijk authored the trilogy Spheres, in which he examines the history of western civilization through the image of the bubble (the title of the first volume) and the globe (the title of the second volume; the third volume is titled foam, a mass of bubbles). In these books, Sloterdijk is able to connect phenomena as diverse as religious conceptions of the universe, greenhouses and spaceships, because in each of them he detects a movement of delimitation or shielding off that allows for the construction of something within these limits: the interior is the condition for an interiority.

One of Sloterdijk's sources of inspiration for the trilogy is the work of Estonian biologist Jacob von Uexküll and more specifically his notion of Umwelt. Uexküll also happens to be of great significance to the philosophical tandem Gilles Deleuze and Félix Guattari. The latter are usually subsumed under the heading of poststructuralism, a "school" in continental philosophy that originated in the sixties of the previous century and ended somewhere at the end of it. Other poststructuralist authors include Jacques Derrida, Michel Foucault, Roland Barthes and Julia Kristeva.

However, Deleuze and Guattari appear to make different use of Uexküll's insights than Sloterdijk: instead of stressing the necessity of a delimitating movement, they focus on the interactive character of Umwelt or, rather, on the fact that it includes a dialogue between parts of entities and thus presupposes a movement of opening up pre-established entities. Is this observation correct? And if so, does this difference in focus reflect a more general difference of nature between poststructuralism and the philosophies that came to succeed it? Is it, for example, an illustration of the revolutionary nature of poststructuralism (decentering, destabilizing, desubjectivization) versus the more pragmatic stance of the philosophers that work with the legacy of poststructuralism?

It will become clear that, in both Deleuze and Guattari's as well as Sloterdijk's philosophies, there are elements to be distinguished that undermine or, at least, nuance this observation. With respect to Deleuze and Guattari, we can refer to the notions of "armature" (Francis Bacon. The logic of sensation) and "house" (What is Philosophy?). To nuance the characterization of Sloterdijk's philosophy, we will look at the multiple and transformative nature of his interiorities, the aspects that prevent these interiorities from turning into absolute interiorities that no longer need an outside. In the final part of this article, we will reassemble all the arguments and try to determine what might constitute the difference between a Deleuzo-Guattarian interiority and a Sloterdijkian interiority.

Sloterdijk's notion of the bubble presupposes a movement of closure. Sloterdijk's notion of the bubble is inspired by Uexküll's notion of Umwelt. Who is this biologist and what does Umwelt refer to?

Jacob von Uexküll is known for having introduced a new school in theoretical biology: ethology. In contrast to the taxonomic approach of classical theoretical biology, which consists in studying living organisms according to their lineage and shared features, Uexküll believes one cannot know the organism without observing how it relates to its environment. A living organism is first of all defined by the specific relationship it maintains with its environment, rather than by its specific corporeal features. Instead of departing from a human point of view, Uexküll thus tries to look through the eyes of the organisms themselves: how do they see the world? What part of the world is meaningful to them? What does this tell us about the organism itself? What counts is thus less what organisms are, but more where they are and how they are; that is, how they interact with the environment in which they are living. According to Uexküll, organisms do not merely occupy an environment, they create it. Their relation to the environment is not a given, but is in constant development. Uexküll thus exchanges the static and passive view of taxonomic biology for one that is dynamic and creative. This development does not occur solely on account of the animal: it is not the case that the animal is merely shaping its environment, but that the animal is likewise shaped by its environment. Animal and environment encounter each other in a contrapuntal relationship of reciprocal determination, the "animal is produced by the production of a milieu" as Merleau-Ponty describes Uexküll's thesis (Merleau-Ponty, 2003: 173); the animal is thus a product, an effect of something it has produced itself. Animal and environment make up an indivisible biological unity: an Umwelt or milieu. ${ }^{1}$

In his foreword to A Stroll Through the Worlds of Animals and Men, Uexküll proposes that we consider Umwelt, the composite unity of the living organism and its environment, as a soap bubble: "The best way to begin this stroll is to set out on a sunny day through a flower-strewn meadow that is humming with insects and fluttering with butterflies, and build around every animal a soap bubble (Seifenblase) to represent its own environment (Umwelt) that is filled with the perceptions accessible to that subject alone. As soon as we ourselves step into one of these bubbles, the surrounding meadow (Umgebung) is completely transformed. Many of its colourful features disappear, others no longer belong together, new relationships are created. A new world emerges in each bubble." (von Uexküll, 1957: 5)

The metaphor of the soap bubble suggests that the world with which the living organism interacts is limited. ${ }^{2}$ Its limits are not so much determined by the physical limitations of the living organism (in the sense that, for instance, the world of a goldfish does not comprise the air because the goldfish does not possess lungs) but instead, these limits are determined by the way in which the living organism addresses the world. Umwelt refers to the world only insofar as it interests the organism: "The Umwelt forms a figurative perimeter around the organism, "inside" of which certain things are significant and meaningful, and "outside" of which other things are as good as nonexistent insofar as they are "hidden in infinity"' (Buchanan, 2008: 23-24). As a consequence, there are as many Umwelts as there are living organisms. As Sloterdijk remarks, Uexküll's idea implies a shattering of "monological metaphysics, which explains the world as monocontext and projects it onto a single eye" replacing it with a "pluralistic ontology which introduces so many worlds $[\ldots]$ without having recourse to the hypostasis of an eye of all eyes [...]." (Sloterdijk, 2004: 248-249). Moreover, Uexküll clearly exchanges a mechanistic account of nature for one that is intentional or expressive. Of course this appeal of the living organism towards the world can only happen if the organism has the right physical features (an animal can only address the world in its liquid form if it possesses the physical capacity to extract oxygen from the water), but this does not imply that the physical features of the organism are the first and only ground from which to explain Umwelt. Contrary to Darwin, Uexküll does not want to reduce the examination of the unity of Umwelt to an examination of the physical correspondences between living organism and its environment (for example, animals with a thick fur in cold environments). Instead, he wants to open it up to an examination of how the living organism and its environment relate through their ways of behaving and perceiving - that is, their rhythmic postures, sounds or colours. ${ }^{3}$ 
Sloterdijk takes over Uexküll's idea of living organisms being defined by the way they address their environment: “(...) living is always already living in an Umwelt-and thus also against an Umwelt and in opposition with several exterior Umwelts-, [...]. ${ }^{4}$ With respect to the human organism, Sloterdijk follows Heidegger: he considers the human being an ecstatic creature-that is, a creature whose being consists of being always already outside of itself. The outside, however, is threatening, or at least uncontrollable and untrustworthy. To guard against it, man creates a membrane that shields him from this outside. The membrane enables him to appropriate everything within it, thus recreating an interior. Because of this double movement of, on the one hand, shielding and expulsion, and on the other hand, the creation of an interior, Sloterdijk calls a sphere an "inclusive exclusivity", 5 which results in an immunity, or a resistance against what is outside. Like Uexküll, Sloterdijk's conception of the integrity of an organism and its Umwelt relies on the membrane, which can be considered the principle of this inclusive exclusivity.

According to Sloterdijk, the first bubble in which man finds himself is the uterus. Mother and child form a two-unity that is shattered once the baby is born, or at least threatened by other persons and activities that take up his mother's time. From the moment individuals cease to be poles in a two-unity and participate in a multipolar space, a crisis arises (Sloterdijk, 2011: 54) and the outside presents itself in all its destabilizing force. What follows is a process of "world condensation", 6 of trying to incorporate the strange, the accidental and the exterior. An attempt is made to create an order by transferring the interior onto the exterior (Sloterdijk, 2011: 56). ${ }^{7}$ In Sloterdijk's view, the history of civilization is one of ever-expanding spheres, of constructing circles that include more of the outside: from the tribe to the people, from the village to the town and the nationstate, from the landlord to the political party, and so on. The historical highlights of this evolution are metaphysical and theological monocentric constructs. Today, these have been torn down. Or rather, they have collapsed under the aporetic tension between community and immunity, and once their expansion crosses a critical threshold, they acquire an autoimmune deficiency. The all-embracing sphere has exploded, or imploded, depending on your perspective.

Sloterdijk claims, and here he is following Heidegger as well (Sloterdijk, 2011: 333-342), that this shielding is vital for man: "They (humans) flourish only in the greenhouse of their autogenous atmosphere." (Sloterdijk, 2011: 46). There is no such thing as human life in the state of nature, naked and alone. To reproduce and individuate himself, man needs a place that is familiar and that he shares with other people or other things. Coexistence precedes and conditions existence. This does not mean that man is the one instigating and controlling this process of sphere construction. It is rather a self-organizing process (Sloterdijk, 2011: 79); the bubble is created by the inspiration or animation that is common to the inhabitants of the sphere-subjects and objects!-, and that causes them to address one another such as to create a shared space of experience (Sloterdijk, 2011: 45). Contrary to Kant, who considers space to be the condition of possibility of a sensus communis, Sloterdijk reverses this relation: the being-together conditions the creation of a space.

Moreover, this movement of closure, of folding into oneself, is not only primary for anthropogenesis but for the genesis of every kind of living organism. Life begins under a form of interiority. An organism comes to be in and through these delimiting, identifying movements. Identity or self-reference is the result of an initial cell membrane: skin, feathers, a cave, a city wall, a witch circle, a symbolic structure, and so on.
Deleuze and Guattari's notion of multiplicity presupposes a movement of opening up. Deleuze and Guattari adhere to Uexküll's idea that the living organism and its environment form a dynamic and expressive unity whose origin cannot be relegated to either one or the other. However, Deleuze and Guattari's relational conception of the living organism slightly differs from Uexküll's in the sense that they consider the relation between organism and environment to be a relationship of affects, rather than a relationship between bodies. ${ }^{8}$ They read Uexküll in a Spinozistic manner. Why? "Affect" is a central notion in Spinoza's Ethics. In contrast to an affection (affectio), which "refers to a state of the affected body and implies the presence of the affecting body", an affect (affectus) "refers to the passage from one state to another, taking into account the correlative variation of the affecting bodies" (Deleuze, 1988: 49). An affect thus indicates first of all a relation or a transition and not merely the state of a body. However, other than Spinoza-who still includes the organic unity of the body in his definition of the affect-, Deleuze and Guattari completely drop the unitary frame of reference that is the organism. An affect is, as they call it, a "pure becoming" because it refers to the passage between different bodies, between different states of one body, or between parts of different bodies. One of Deleuze and Guattari's preferred examples of such an affecting relation is the relation between an orchid and a wasp. They describe it as a "love relationship", thereby indicating a contrast with a Spencerian conception of nature in terms of struggle and competition. According to Deleuze and Guattari, the orchid-wasp relation does not imply a collaboration in the sense of the orchid providing nectar for the wasp and the wasp simultaneously helping with the reproduction of the flower. Rather, we are dealing with a new functional unity which does not include the orchid or the wasp, but only some of their parts. These are the reproductive organ of the wasp and the feature of the orchid that resembles the protrusion of the female wasp: some orchids seduce male wasps by imitating this protrusion, even to the degree of bringing the male wasp to orgasm. These parts are hence detached from the entities to which they are supposed to belong and constitute a new machinic assemblage. Deleuze and Guattari write that the wasp is a "liberated piece of the orchid's reproductive system" and the orchid, "the object of an orgasm in the wasp, also liberated from its own reproduction" (Deleuze and Guattari, 2004: 324).

The affecting-affective-relationship characterizing Umwelt thus implies a deterritorialization, a breaking of "natural" or "original" boundaries, a crumbling of identities in a collective becoming. This "becoming is not a correspondence between relations", as Darwinism states, and neither is it "a resemblance, an imitation, or, at the limit, an identification", like the everyday meaning of the word "becoming" suggests (Deleuze and Guattari, 2004: 262). Rather, it is something that takes place beneath the level of identities. For example, in order for the orchid-wasp collaboration to work, the orchid has to become wasp-like and vice versa. But these becomings do not presuppose that the changed orchid and the wasp will have some characteristics in common. Instead, both terms of the relation change. We can explain this by referring to another example used by Deleuze and Guattari, that of the bird Scenopoïetes dentirostris. This bird plucks leaves from the trees and places them upside down, with their white underside towards the sky, so as to create a contrast with the brown soil. The soil and the leaves arranged by the bird form a new unity, a piece of art according to Deleuze and Guattari. This unity cannot be reduced to a combination of bird and soil: it can neither be reduced to a reaction of the bird to its environment (scarcity of the females that need to be seduced by all possible means, for example), nor to an interaction of bird and environment (in the sense that bird and environment shape each 
other). The reason is that this new unity consists of elements that did not exist before. Before the bird starts turning leaves, neither the bird-artist nor the soil-canvas exist.

Beside the notion of becoming, Deleuze and Guattari use another concept to express their politics of cracking identities: multiplicity. Every living being is a multiplicity. ${ }^{9}$ In contrast to identities that are indivisible, multiplicities are composed of heterogeneous elements. Furthermore, they are intensities, as being opposed to extensive unities. Extensive unities have the property of being partes extra partes, they are the sum of subentities that are all of the same nature. An extensive unity is cardinal. A dozen, for example, is the sum of 12 identical unities, namely 12 "ones". A crate of beer is the collection of 24 identical bottles of beer. An intensity, by contrast, cannot be subdivided into homogeneous elements. A temperature or a speed, for instance, is not composed of other temperatures or speeds. The cardinal translation of a temperature $\left(25^{\circ} \mathrm{C}\right)$ is, but the warmth of a nice sunny afternoon in August is not: a nice sunny afternoon in August is not the sum of four cold afternoons in January. An intensity is determined by an asymmetrical relation between heterogeneous elements: the absence of wind and a high humidity level are decisive for how warm it feels. Moreover, the composition of an intensity cannot be changed without the nature of the intensity changing. When I take away half of the bottles in a crate of beer, the quantity has diminished but the quality has remained the same. When the temperature drops by $50 \%$, on the other hand, it is no longer a warm sunny afternoon. Thus, a multiplicity consists of different qualities folded into one another, while simultaneously being irreducible to one another.

Whether Deleuze and Guattari describe living organisms in terms of affects, becomings or multiplicities, what remains constant in these notions is the movement of breaking interiorities and opening them onto other forces, elements or aspects. The ultimate aim of Deleuze and Guattari seems to be the making of connections in such a way that what is connected does not form a unity in which differences are annihilated. As Brett Buchanan observes, "with Deleuze and Guattari, [...], the soap bubble has burst” (Buchanan, 2008: 175).

Intermediary conclusion. So far, the difference between the thinking of Deleuze and Guattari, on the one hand, and Sloterdijk, on the other, appears to be the following: whereas the first believe in the generative qualities of the encounter with the exterior, the latter focuses more on the importance of closing off and selectively refusing participation. Instead of experimenting with all sorts of possible connections with what does not belong to an identity, Sloterdijk starts from the immunitary interests of particular beings. "By nature, life only comes out well in the finitude of an individualized immune system". ${ }^{10}$ There is a primacy of shielding above participation (Sloterdijk, 2004: 196).

Another, maybe less polemic, way of describing the contrast between both philosophies is to say that Sloterdijk's spherology is motivated by an interest in spatializing the phenomenological description of Umwelt, whereas Deleuze and Guattari's approach (especially Deleuze's) seems to be fundamentally temporal. For example, Sloterdijk presents his concept of bubble as an alternative to the "anorectic" notion of a network: contrary to the nodes of a network, bubbles are "incompressible" occupations of space (Sloterdijk, 2005: 391-406). Deleuze and Guattari's rhizomatic network philosophy, on the contrary, stresses the nomadic aspect of Umwelt, its constant metamorphosis. They are interested in how bubbles will morph into other bubbles and generate new functional relations and immune systems. They are interested in the expressive qualities of bubbles, rather than in their possessive ones. 11
However, despite this difference in focus, each of the aforementioned philosophies also contains ideas and notions that link with their so-called opposite. In Deleuze and Guattari, we can find elements that reveal an interest in closure and, vice versa, there are also poststructuralist elements of breaking down identities to be found in Sloterdijk.

\section{Closing movements in Deleuze and Guattari}

In his brilliant discussion of Francis Bacon's paintings, Francis Bacon. The logic of sensation, Deleuze uses two notions that are of interest to us: "armature" (armature) and "frame" (charpente). As they are closely related to the notion of "house" that Deleuze and Guattari use in What is Philosophy? to talk about art and the art of animals, we consider it legitimate to use them in a context larger than the art of Francis Bacon alone. Let us first see what "armature" and "frame" mean in Bacon's paintings, after which we can extrapolate their significance.

Deleuze claims that every painting by Bacon contains three elements: first, the Figure-which he also calls the body or the head-, second, the armature-also known as the field (aplat) or material structure-, and finally the ring (la piste) - also described as the round area (le rond) or the contour. The Figure refers not to the main character of the representation, but to the (part of the) body presented: Bacon wants to break narration and representation and create a non-resembling resemblance with reality, a presence. The Figure is a subject without identity and without a place in the story. It always escapes itself. It is always free falling. However, to prevent the Figure from actually disappearing, it is contained first by a small ring or round area, then by a larger monochrome field. This field or armature cannot be considered the background of the Figure: Bacon exchanges a classical relation of figure and ground-of depth, in other words -for a haptic or shallow depth. The field surrounds the Figure, rather than being placed behind the Figure. The contour is the membrane through which armature and Figure communicate. According to Deleuze, the armature has a structuring and spatializing function. It divides the space, creates sections and regions, for example, by varying the intensity or saturation of the coloured field and by introducing bars or ribbons. The goal of the armature is to prevent the destabilizing forces of the Figure from spreading out to the whole painting, to prevent colours from mixing into a dead grey and planes from stumbling over one another. However, the painter must be careful not to exaggerate this structuring function such that he ends up with the rigid and clichéd structure of representation. Deleuze calls Bacon's art of keeping this fragile balance the "diagram".

When Deleuze discusses Bacon's diagram, he distinguishes a pair of forces that is very similar to the function of the Figure and the armature: the sensation and the frame (charpente). When making his paintings, Bacon cannot only rely upon sensations or the ways in which his nervous system is directly affected by colours and forms. Sensations are "ephemeral and confused, lacking duration and clarity" (Deleuze, 2005: 79). To give them a structure that can hold them and force them to take shape, he needs the frame. The frame alone, however, is useless because it is too abstract. The sensations allow the frame to be concrete, to be felt (Deleuze, 2005: 79). In sum, whether Deleuze analyses Bacon's paintings or Bacon's working method, he always finds the same pair of forces: on the one hand, the force that breaks down recognizable entities (identities, narrative structures, causalities, and so on.) and allows them to be invaded by foreign elementsthe so-called deterritorializing forces-and on the other hand, the forces that try to consolidate and structure the new connections that are being made (without, however, ending up with a cliché) - the so-called reterritorializing forces. ${ }^{12}$ 
In What is Philosophy?, Deleuze and Guattari call the two forces present in every art work, the "house" (maison) and the "cosmos" or the "universe" (cosmos, univers). "Now, what defines the house are "sections," that is to say, the pieces of differently oriented planes that provide flesh with its framework (armature): foreground and background, horizontal and vertical sections, left and right, straight and oblique, rectilinear and curved" (Deleuze and Guattari, 2003: 179). The "house" is thus what was called the "armature" in Francis Bacon. The logic of sensation, it is the territorializing force. The house protects us from the cosmos or the deterritorializing forces, though it can never completely keep them outside: "at most it filters and selects them. (...) But equally, the most baleful forces can come in through the half-open or halfclosed door (...)" (Deleuze and Guattari, 2003: 182). The universe, on the other hand, "supports" the house (Deleuze and Guattari, 2003: 180) in the sense that it consists of the insensible forces that traverse the world and constitute it. Despite Deleuze and Guattari clearly indicating that an art work requires both forces, the fact that they claim that architecture is the first of the arts (Deleuze and Guattari, 2003: 186) testifies how important they consider the territorializing force to be. "The most scientific architecture endlessly produces and joins up frames and sections" (Deleuze and Guattari, 2003: 186). They also refer to the care and respect that is implied in the reterritorializing activity (Deleuze and Guattari, 2003: 179): one recognizes a great artist not by the violence with which he destroys and opens up existing structures, but by the care he gives to structuring what has been deterritorialized.

Opening movements in Sloterdijk. According to Sloterdijk, every sphere-that is: every construction as a shield against the outside-consists of at least two poles. An example of a bipolar sphere is the unity of mother and child in utero, but there are also multi-poled bubbles like the intimate group sessions of animal magnetism that Sloterdijk describes in his novel The Magic Tree. This observation implies, first, that the inner space is never pure; it is always the conjunction of the proper or the interior with the non-proper or the exterior (Sloterdijk, 2004: 536-537). A sphere is always heterogeneous; it is a multiplicity without a first or primary pole. The poles are "originally complementary". Second, it means that the attacks from the outside not only threaten the inner space, but also strengthen it and even form its condition of possibility (Sloterdijk, 2011: 45-46). A bubble is what it is capable of becoming, insofar as it is already the other that it becomes in the mutually constitutive relation.

Moreover, although bubbles are shielded from the outside, they are always communicating with it. They are not self-concealed and isolated but reach out for accompaniment and overlap. Sloterdijk proposes that we think of this communication in terms of foam. In a physical way, foam refers to the product achieved when inserting air into liquid (as in beer foam) or into firm matter (as in lava rock). This entity, halfway between a liquid and a solid, is constituted by multiple cells, each separated by membranous partitions. The cells can invade their neighbours and transmit their volume to them. Foam is stable-that is, cells stop invading one another-when the tension is well spread among all the bubbles, when the different bubbles have reached an optimal interdependency. In contrast to classical entities, the unity of the foam is thus not determined by something identical or indivisible, but by a difference (in tension or in intensity). This is clearly a very Deleuzian idea.

In general, we can say that Sloterdijk's foam theory is intended to turn upside down the classical thinking in terms of substances, just as Deleuze is trying to invert Platonism. Instead of focusing on what is indivisible, what exists in and of itself and what is unchangeable, Sloterdijk's foam is heterogeneous, outside of itself and thus always in transformation. Its ephemeral nature-the fact that air or nothingness is a fundamental part of foam and thus that it is "almost nothing", that "its presence is constituted by absence" (Sloterdijk, 2004: 32-34)—contrasts with the solid nature of classical, Platonic forms that are the acme of presence. Moreover, in contrast to the unidirectional nature of the substance-a substance conducts, founds or creates-, foams are "two-way systems" (Sloterdijk, 2011: 41) in which no origin can be discerned. In sum, with his notion of foam, Sloterdijk gives the volatile, the insignificant and the secondary, the attention that used to be preserved for the ever-being, the substantial and the primary. "That which has been treated in a step-motherly way for centuries, a seemingly frivolous surplus of existence, [...], will now regain its share in the definition of the real. Then one will understand that the floating can serve as a special kind of foundation, that the hollow can be described as an autonomous fullness, that the fragile can be considered the place and mode of the most real, that the unrepeatable is a phenomenon of a higher order than the serial." 13

The heterogeneous nature of the bubble, the differential nature of the foam and the re-evaluation of the empty can all be considered affirmations of the constitutive power of the movement of opening up, and thus complements Sloterdijk's initial founding movement of closure.

\section{Conclusion}

Now that we have given counterarguments to the hypothesis that the primary movement in Deleuze and Guattari's philosophy is one of opening up, whereas Sloterdijk's thinking is primarily characterized by closure, we have to reconsider the question of the difference between these thinkers. The hypothesis of a contradiction can be discarded, not only because there is textual proof that connects each position with its opposite, but also, and more importantly, because a closer look indicates that these positions do not necessarily present opposite ends of one and the same line. We would like to propose the idea that Deleuze and Guattari's observations are situated on an ontological level, whereas Sloterdijk's focus is existential. To explain this, we must examine the nature of the communication with the outside in each of the positions.

Sloterdijk's image of the foam suggests that the communication between bubbles is indirect and, more importantly, unintended. It is a by-product of the way bubbles are constituted. In foam, one and the same partition does not only mark the end of one bubble but also the beginning of the next. Bubbles are at the same time separated from and connected to each other. They coexist as separate entities-Sloterdijk uses the term "co-isolation"-and this co-isolation is the actual agent of the formation of space. ${ }^{14}$ This means that movements within one bubble necessarily have implications for the surrounding bubbles. If one bubble expands, this will make the neighbouring bubbles shrink, except if these neighbours also swell and force their neighbours to shrink. Foam, then, is the result of this indirect communication between bubbles.

In Deleuze and Guattari, on the contrary, the communication with the outside is not a by-product but a mission. It is not an unintended consequence but a goal we must aim at. We have to tear down the tired ideas of what it is to be human and allow ourselves to let animal traits trickle into our self-image (the socalled becoming-animal or becoming-molecular). We have to leave the known paths of how things are being said and start stammering (Deleuze and Guattari, 2004: 109). Or as Isabelle Stengers has pointed out, Anti-Oedipus contains an accelerationist categorical imperative to deterritorialize and destroy 
everything that reeks of sedentariness (Stengers, 2009: 265-266). In other words, we should be open to any kind of exterior that shakes the boundaries and layers of territories.

Some scholars think this moral prescription (we have to) is in contradiction with the amoral essence of Deleuze and Guattari's philosophy. Since Deleuze and Guattari do not accept any authority, they cannot prescribe any kind of behaviour. This is true. However, in this situation, it is not some kind of authority that commands this behaviour, but life itself. Deleuze and Guattari can plea for deterritorialization not because it is valuable in itself, not because it is a principle (like moral values), but because it is a condition for life; without these deterritorializations, life becomes ossified and dies out. So, while one must pursue communication with the outside, this occurs as an ontological necessity and not a moral imperative.

Sloterdijk, on the contrary, observes that we should not always be hospitable in facing the exterior (Sloterdijk, 2011: 75). Not only should we accept that there will always be something of the exterior that will remain exterior, ${ }^{15}$ it should also be like this. Exclusivity, flaws in the communication with the other, and negation (as it is implied in the exclusion of sheer exteriority from Umwelt) are affirmative virtues. ${ }^{16}$ Why is this? Why are we not allowed to incorporate exteriority completely, even if we would be capable of doing it? According to Sloterdijk, one must defend one's "antagonistic" interests (Sloterdijk, 2004: 195) because one can only welcome other selves when the inner space that allows for the construction of one's self is taken care of. The construction of the inner space presupposes a kind of naiveté with respect to the exterior-he calls it "reimplication" (Sloterdijk, 2004: 202)— which does not mean that the exterior is ignored but that one has the freedom not to take into account certain parts of this exterior.

To conclude: Sloterdijk's position with respect to interiority differs from Deleuze and Guattari's not because their ontological insights diverge-on the contrary, Sloterdijk recognizes the ontological necessity of all kinds of movements that open up interiorities (heterogenesis, multiplicities, transformation, porosity, etc.), -, but because he draws attention to the existential difficulties associated with these movements. This difference cannot be reduced to the mere opposition between conservatism and progressive socialism because-as Isabelle Stengers observes (Stengers, 2003: 372)-the fascination for change and difference might be the acme of tolerance but it is also the cause of irrecoverable damage.

\section{Notes}

1 Because this concept has been translated in various ways, not only in the English translations of Uexküll's work (now as "environment", then as "milieu"), but also in the English translations of authors that have employed this concept (such as Sloterdijk, Merleau-Ponty, and so on.), we prefer to use the original German term.

2 "The space peculiar to each animal, wherever that animal may be, can be compared with a soap bubble which completely surrounds the creature at a greater or less distance. The extended soap bubble constitutes the limit of what is finite for the animal, and therewith the limit of its world; what lies behind that is hidden in infinity." (von Uexküll, 1927: 42)

3 As an example of an Umwelt, we can refer to the world with which the tick forms a unity. The Umwelt of a tick is reduced to three dimensions: light, odor and warmth. Light, which the tick perceives with its photoreceptive skin, guides the tick towards the top of a branch. Odor (of the butyric gland of mammals) makes the tick release itself from the branch and fall onto the back of the mammal passing underneath the tree. And warmth leads the tick towards the least furry spot on the mammal's body, where it can enter the skin and suck blood. Everything else in the tick's external surroundings is without significance for the tick: the weather, the presence of nonmammals, the type of mammal, sounds, and so on. The Umwelt of a medusa is even more restricted than that of the tick: a medusa can hardly be said to address the world as its behavior has almost no relation to the environment. The only thing a medusa does is breathe oxygen, move about and open its digestive tube. But as these actions never change according to external circumstances-the passing of an edible substance will not, for instance, affect the opening of the digestive tube, it opens at random-it almost does not have an environment. As we move up the hierarchy of animals, the size of the soap bubble will increase or, to say it differently, the world will be addressed in a more differentiated way. In contrast to a tick, the world of a dog contains living beings that are not immediately relevant for its food supply (namely those who threaten its existence or those it can play with), in a dog's world there is a distinction between sunny and rainy weather (in the last case it will look for shelter, whereas in the first it will sunbathe), and so on.

4 "Finding that living is always already living in an Umwelt-and thus also against an Umwelt and in opposition with several exterior Umwelts-, [...]” (“ Mit der Feststellung, dass Leben immer schon Leben in einer Umwelt ist—und somit auch gegen eine Umwelt und in Oppositionen zu vielen fremden Umwelten -, [...]", Sloterdijk, 2004: 193-194; translation modified)

5 "Immunity, as local aseity, originates from the praxis of good limitation-it is the limit case of inclusive exclusivity." ("Immunität, als lokale Aseität, entspringt der Praxis guter Limitierung-sie ist der Ernstfall von inklusiver Exklusivität", Sloterdijk, 2004: 538).

6 The German verb "dichten" from which the term "(Welt)dichtung” is deduced, has the double meaning of, on the one hand, to fill or to plug (a hole in a sock, for example), and on the other hand, of poetry. The noun "Dichte" means density. The English translation of Weltdichtung, "world literature" (Sloterdijk, 2011: 56), neglects the first meaning of dichten, which is, in the context of the process of incorporation that Sloterdijk describes, the most important one. This is the reason why we decided to deviate from Hoban's translation and choose our own: "world condensation".

7 In this context, Sloterdijk refers to Le Corbusier's words "The exterior is the result of an interior" ("Das Aussen ist das Ergebnis eines Innen"- Sloterdijk, 2004: 65).

8 "You will define an animal, or a human being, not by its form, its organs, and its functions, and not as a subject either; you will define it by the affects of which it is capable" (Deleuze, 1988: 124).

9 See also: "Every animal is fundamentally a band, a pack", "a population" or "a peopling" (Deleuze and Guattari, 2004: 264).

10 "It (classical metaphysics) breaks up in the attempt to defend the case of life, which by nature only comes out well in the finity of an individuated immune system, [...]." ("Sie (die klassische Metaphysik) zerbricht daran, dass sie die Sache des Lebens verteidigen will, das naturgemäss nur in der Endlichkeit eines individuierten Immunsystems aufgehoben ist, [...]", Sloterdijk, 2004: 19).

11 This could maybe explain why Deleuze and Guattari never thematize the concept of Umwelt as such, unlike phenomenologists such as Heidegger, Merleau-Ponty and Sloterdijk. Deleuze and Guattari are not so much interested in the being-in-theworld, in the nature of the space that man arranges for himself and by which he is arranged, that he possesses and by which he is possessed, but in the becoming of the world, in the evolution of this bidirectional process. (Buchanan, 2008: 176-177, 189).

12 Deleuze distinguishes these two forces also within the Figure: flesh and bones (Deleuze, 2005: 23).

13 "Das weltalterlang Verächtlich-Gemachte, das scheinbar Frivole, [...] gewänne seinen Anteil an der Definition des Realen zurück. Man begreift dann: das Schwebende ist als Grundgebendes besonderer Art zu verstehen; das Hohle als eine Erfülltheit eigenen Rechts neu zu beschreiben; das Fragile als Ort und Modus des Wirklichsten zu bedenken; das Unwiederholbare gegenüber dem Seriellen als das höhere Phänomen zu erweisen." (Sloterdijk, 2004: 39).

14 The same principle of co-isolation or co-immunism is present in Buckminster Fuller's architectural principle of construction called tensegrity (Sloterdijk, 2004: 472-473). As the word itself indicates, a tensegrity refers to the integrity of structures that is based on the equilibrium between the push and pull loads. The pulling forces are absorbed by flexible cables or tendons, whereas the pushing forces are absorbed by bars or struts. Contrary to "classical" constructions, similar elements never touch one another (isolation) and every element is necessary in order to hold the construction. If one removes a single element, the construction collapses.

15 "No institution, [...]-let alone an individual who reads on bravely-can imagine that it is sufficiently open for everything that infiltrates, speaks and encounters it; viewed from any point in our lifeworld, the vast majority of individuals, languages, works of art, commodities and galaxies remain an unassimilable outside world, by necessity and forever" (Sloterdijk, 2011: 76).

16 "Each house, as base for a finite capacity to live, generates exclusivity; each punctual self-affirmation produces flaws in communication and negation of the Umwelt. This is its affirmative virtue, [...]." ("Jede Wohnung, als Stützpunkt eines endlichen LebenKönnens, erzeugt Exklusivität; jede punktuelle Selbstbejahung produziert Kommunikationsabbrüche und Umweltverneinung. Das ist ihre affirmative Tugend, [...]", Sloterdijk, 2004: 544).

\section{References}

Buchanan B (2008) Onto-Ethologies. The Animal Environments of Uexküll, Merleau-Ponty, and Deleuze. State University of New York Press: New York, NY.

Deleuze G (1988) Spinoza. Practical Philosophy. City Lights Book: San Francisco, CA. Deleuze G (2005) Francis Bacon. The Logic of Sensation. Translated by Daniel W. Smith. Continuum: London.

Deleuze G and Guattari F (2003) What Is Philosophy? Translated by Graham Burchell and Hugh Tomlinson. Verso: London/New York. 
Deleuze G and Guattari F (2004) A Thousand Plateaus. Translated by Brian Massumi. Continuum: London.

Merleau-Ponty M (2003) Nature: Course Notes from the College De France. Translated by Robert Vallier. Northwestern University Press: Illinois: Evanston.

Sloterdijk P (2004) Sphären III: Schäume. Suhrkamp Verlag: Frankfurt am Main. Sloterdijk P (2005) Im Weltinnenraum Des Kapitals: Für Eine Philosophische Theorie Der Globalisierung. Suhrkamp Verlag: Frankfurt am Main.

Sloterdijk P (2011) Spheres I: Bubbles. Translated by Wieland Hoban. Semiotext(e): Los Angeles, CA

Stengers I (2003) Cosmopolitiques ii. Mécanique Quantique, Au nom de la Flèche du Temps, La vie et L'artifice, Pour en Finir Avec la Tolerance. La Découverte: Paris.

Stengers I (2009) Leven/denken. In: Romein E, Schuilenburg M and van Tuinen S (eds). Deleuze Compendium. Uitgeverij, Boom: Amsterdam.

von Uexküll J (1927) Theoretical Biology. Translated by DL Mackinnon. Harcourt, Brace: New York, NY.

von Uexküll J (1957) A stroll through the worlds of animals and men. Translated by Claire Schiller. In: Schiller C (ed). Instinctive Behavior: The Development of a Modern Concept. International Universities Press: New York, NY.

\section{Data availability}

Data sharing not applicable to this article as no datasets were generated or analysed during the current study.

\section{Additional information}

Competing interests: The authors declare no competing financial interests.

Reprints and permission information is available at http://www.palgrave-journals.com/ pal/authors/rights_and_permissions.html

How to cite this article: Wambacq J and van Tuinen S (2017) Interiority in Sloterdijk and Deleuze. Palgrave Communications. 3:17072 doi: 10.1057/palcomms.2017.72.

Publisher's note: Springer Nature remains neutral with regard to jurisdictional claims in published maps and institutional affiliations.

(c) (i) This work is licensed under a Creative Commons Attribution 4.0 cc International License. The images or other third party material in this article are included in the article's Creative Commons license, unless indicated otherwise in the credit line; if the material is not included under the Creative Commons license, users will need to obtain permission from the license holder to reproduce the material. To view a copy of this license, visit http://creativecommons.org/licenses/by/4.0/

(C) The Author(s) 2017 